\title{
The Changing Face of Entrepreneurship in Germany
}

\begin{abstract}
This paper explains individual start-up activities on the basis of both person-related characteristics and the regional context. The analysis is based upon micro data from the GEM adult population survey. Both individual and regional variables have an influence on the decision to become self-employed. There are considerable differences between nascent opportunity entrepreneurship and nascent necessity entrepreneurship. Whereas the results for opportunity entrepreneurship are in line with theoretical predictions the factors influencing necessity entrepreneurship are far more difficult to determine. The most significant change between 2001 and $2003 / 2004$ is the reversal of the influence of a change in the regional rate of unemployment on nascent entrepreneurship activities.
\end{abstract}

KEY WORDS: Entrepreneurship, regions, Germany, Global Entrepreneurship Monitor.

JEL CLASSIFICATIONS: R12, L26, J23.

\section{Introduction}

Entrepreneurship in general and start-ups in particular have become a focal point in politics, economics and social sciences in Germany for various reasons. Politics only discovered startups fairly recently, but then quickly developed a range of initiatives and programmes. As the Global Entrepreneurship Monitor (GEM)

Final version accepted on October 2006.

Heiko Bergmann

Swiss Research Institute of Small Business

and Entrepreneurship

University of St. Gallen

Dufourstr. 40a, CH-9000, St. Gallen, Switzerland

E-mail: heiko.bergmann@unisg.ch

Rolf Sternberg

Institute of Economic and Cultural Geography

University of Hannover

Schneiderberg 50, D-30167, Hannover, Germany

E-mail: sternberg@wigeo.uni-hannover.de country reports for Germany show, government programs regularly count among Germany's comparative strengths as entrepreneurial framework conditions (see, e.g., Sternberg, 2000; Sternberg and Bergmann, 2003; Sternberg et al., 2004). According to the current GEM country report for Germany for the year 2005 (see Sternberg et al., 2006), Germany actually holds fourth place among the 33 GEM countries which carried out the relevant expert surveys. Whereas start-ups are taken for granted as a practical institutionalisation of the dream of independence held by immigrants to the USA or Australia, European countries such as Germany have only recently placed the subject of entrepreneurship at the centre of their economic policies.

Hopes in Germany are that the numerous promotional programmes at national, Bundesland (state) and municipal level will make a positive contribution to the development of the labour market. Start-ups became a hot topic in politics partly out of conviction (ambitions to create an "entrepreneurial society") and partly out of necessity (the realisation that large companies in the past have made job cuts, while start-ups really can only grow).

There has been an absolute and relative increase in necessity entrepreneurship in Germany as a response to changes in the prevailing economic conditions and new policy measures affecting the labour market. For several years, GDP growth in Germany has been at the level of the European average at best, and certainly too low to be able to trigger substantial employment stimuli. The labour market problems are a serious worry. For many once dependent employees, the high rate of unemployment $(10.5 \%$ in July 2006$)$ is making self-employment look like a serious alternative, particularly in view of the economically far less 
attractive prospect of receiving unemployment or welfare benefits. "Hartz IV', the most important reform programme focusing on the labour market and social policy in Germany in the years 2003-2005, explicitly pursues the goal of bringing the unemployed to the labour market more quickly. Attempts to achieve this include push factors (cutting the level of welfare and unemployment benefits, obligation to accept very low-paid work) as well as pull factors, e.g. instruments intended to make the step towards self-employment easier ("Me Inc." ("Ich- $A G$ "), bridging allowances). The "Ich- $A G$ " in particular has proved to be very popular, partly because it involves immediate financing in the form of an interest-free but limited-duration subsidy of $600 €$ in the first year, $360 €$ in the second year and $240 €$ in the third and last year. The move into self-employment is almost risk-free for unemployed people because they can quit their new business at any time, return to unemployment and again receive their previous level of unemployment benefits. The temporary phase of self-employment does not have any effect on their entitlement to unemployment benefits. It is still too early to make any assessment but it is certain and plausible that these start-ups typically have little growth intentions and growth prospects different from opportunity entrepreneurs. The majority of necessity entrepreneurs are primarily looking to safeguard their own living, not to generate revenue growth or additional jobs. Almost two thirds of all newly self-employed persons in 2003 were unemployed before entering self-employment (see Centre for European Economic Research, 2004).

From a regional point of view, the high proportion of formerly unemployed persons among all founders of a new company - which is certainly specific to Germany - is relevant for several reasons. First, necessity entrepreneurship varies considerably between individual federal states and even between planning regions. Second, the individual entrepreneurial attitudes also differ greatly between German regions (see Sternberg and Bergmann, 2003), which in turn - according to our hypothesis of the relevance of regional framework conditions for an individual's decision to start (or not to start) a company - may at least partially explain the differing regional extent of necessity entrepreneurship. And third, the economic and social conditions vary between the planning regions which also has an influence on the individual's propensity to start a new business, if Feldman's (2001) hypothesis that entrepreneurship is a "regional event" is correct.

This paper is structured as follows. After the introductory the second section discusses theoretical approaches to explain the role of personal/individual determinants and of regional determinants on an individuals decision to start a firm. The following core section initially describes the methodological approach of the econometric part and then addresses various individual and regional determinants explaining start-up activity. Using logit regression analyses for different time periods we intend to consider the changing macroeconomic conditions in Germany and its regions since 2001. The results are then discussed in the light of policy instruments described above. The last section draws conclusions for entrepreneurship research with a regional perspective.

\section{Theoretical background}

\subsection{Person-related determinants}

\subsubsection{Employment situation, level of education,} professional and entrepreneurial experience

There has long been a debate in entrepreneurship research as to why some people start a business whereas others prefer to stay in paid employment or do not work at all. Labour economic approaches assume that the employment decision is mainly rational: People who intend to pursue gainful employment are faced with the choice of independent and dependent employment (Knight, 1921, p. 271). The decision as to which of these two types of gainful employment is chosen is influenced by their relative attractiveness. This depends on the level of profit or pay expected, the current employment situation and other person-related characteristics. In addition, regional and national framework conditions also influence the attractiveness of the two alternative types of employment. Promotion programmes and other 
political measures make it possible to reduce the monetary and non-monetary costs of a start-up, thereby increasing the attractiveness of a startup relative to dependent employment.

A number of person-related variables can be expected to influence the individual start-up propensity. However, since these influences are well explored and are not the focus of this paper, they are briefly discussed at this point only. These variables will be included as control variables in the empirical part of this paper. Highly qualified people can be expected to have a high start-up propensity since a number of self-employed activities require a certain level of knowledge and skills (see Davidsson and Honig, 2003; Robinson and Sexton, 1994).

Former entrepreneurs or people in selfemployment typically have the knowledge and the capability to launch another start-up and it can therefore be assumed that their entrepreneurial propensity is higher than that of people without such experience. Empirical studies support this conjecture (see Davidsson and Honig, 2003; Wagner, 2003).

\subsubsection{Age and gender}

There are contrasting tendencies in the influence of age on entrepreneurial propensity. On the one hand, expertise, professional experience, selfconfidence and, generally, also the amount of capital available increase with age, which makes entrepreneurial activity more probable. On the other hand, the level of professional and family embeddedness increases with age and the planning horizon for the remainder of the working life decreases, which would tend to weigh against entrepreneurial activity (see Bates, 1995; Schulz, 1995, p. 114ff). Overall, the two contrasting influences demonstrate a reversed U-shaped relationship between age and entrepreneurial propensity, which is also confirmed by most empirical studies: Initially, entrepreneurial propensity increases with age, reaches its peak between the ages of 35 and 40 approximately and then drops off towards the end of the working life (see Bates, 1995; Welter and Rosenbladt, 1998).

The employment behaviour of women differs from that of men, and there are also clear gender-specific differences in entrepreneurial activities (see Carter, 1997; Welter and Lageman, 2003). In most industrialised nations around the world, including Germany, women's entrepreneurial propensity is lower than men's (see Reynolds et al., 2004, p. 35).

\subsubsection{Significance of situational factors as a trigger for the move to self-employment}

There is certainly a broad variety of people who would like to become self-employed, but only a far smaller number of people actually take the plunge. Shapero assumes that human behaviour is characterised by a certain lethargy and that a person will only become entrepreneurially active once there is an event, a "displacement" which changes the course of that person's life. Such triggering events may be negative or positive. According to Shapero, the move to selfemployment is mostly made as a consequence of a negative event, such as losing one's job (see Shapero, 1984, p. 24f; Shapero and Sokol, 1982, p. 79). Bygrave (1997, p. 3) argues that there is almost always a 'triggering event' which leads to the launch of a new firm. Case studies of entrepreneurs point to the significance of chance occurrences in the entrepreneurial process. Such triggering events may be the completion of vocational training, an unexpected inheritance, the successful presentation of scientific results or the impending dissolution of a department.

A triggering event explains why somebody takes the decision to change the course of his or her life. What is cannot explain, however, is why that person actually goes ahead and takes the step to self-employment. Shapero (1984, p. 25) argues that an action is taken if it appears both worth working for and realisable. A person who has been made redundant will therefore only start a business if he or she thinks that his endeavours will lead to a successful start-up.

\subsection{Regional determinants}

\subsubsection{Purchasing power}

The general economic framework conditions in a region have a considerable influence on the level of regional entrepreneurial activities. Most new firms produce for a regional market, at least in the start phase, which explains why the development, structure and level of regional 
demand have a strong influence on the level of entrepreneurial activities. Empirical investigations therefore mostly include such factors as the purchasing power or the population density.

Microeconomic decision models show that people become self-employed when they expect their self-employed activity to generate a high level of profit (see Knight, 1921). As regional demand increases, therefore, more firms are typically launched, as the high level of demand makes self-employed activities lucrative. In a comparison of studies in six European countries (Germany, France, Ireland, Italy, Sweden, the United Kingdom) and the USA, Reynolds et al. (1994, p. 449) come to the conclusion that an increase in demand makes the largest contribution to explaining regional differences in entrepreneurial activities: "No process is more fundamental than reactions to increased demand for goods and services" (Reynolds et al., 1994, p. 446). More recent studies also demonstrate the influence of demand factors on the level of start-ups (for the USA see Armington and Acs, 2002; for Germany see Fritsch and Falck 2002, p. 23; Audretsch and Fritsch, 1994). Empirical studies most commonly measure increased regional demand based on the growth in gross domestic product.

Besides the increase in regional demand, the absolute level of regional demand and the level of income can exert an influence on entrepreneurial activities. Certain types of start-ups, such as in the field of high-value person-related services, may only be worthwhile in regions where many potential customers with a high income live. There is a relatively strong relationship in Germany between the regional level of income and the population density, which is why it is particularly difficult to separate this effect out from general agglomeration effects (see Bartik, 1989; Brixy and Grotz, 2002, p. 117).

\subsubsection{Agglomeration effects}

Most investigations of regional entrepreneurial activities find a positive relationship between population density and entrepreneurial activity: Areas of agglomeration mostly have higher levels of entrepreneurial activity than rural areas (see Brixy and Grotz, 2002; Fritsch and Falck, 2002; Sternberg and Bergmann, 2003; Reynolds et al., 1994). There can be two different reasons for such a relationship: First, due to the aforementioned relationship between the level of income and the population density, the higher level of entrepreneurial activity in areas of agglomeration may be a result of the high level of income. Second, the higher level of entrepreneurial activity may also be attributable to agglomeration effects. Within agglomerations, a pooled labour market, knowledge spillovers and the generally greater provision of non-traded inputs can lead to increasing returns at the spatial level, which has a positive effect on the start-up propensity (see Armington and Acs, 2002, p 37).

\subsubsection{Rate of unemployment}

Where there is a lack of alternative employment, the pressure to go into self-employment is greater for the unemployed than for those in employment. On the other hand, the unemployed often do not have the necessary skills and knowledge to do so. At regional level, too, there are contradictory influences of regional rates of unemployment on the level of entrepreneurial activity. On the one hand, the higher the number of unemployed in a given region, the greater the number of people willing to enter into selfemployment. On the other hand, a high regional rate of unemployment is often accompanied by a low regional level of purchasing power, which has a negative effect on the number of start-ups. Altogether, the overall influence of the region's unemployment rate on new firm formation is therefore indeterminate (Armington and Acs, 2002, p. 39; Storey, 1994, p. 69).

Empirical studies for Germany also generate inconclusive results on the impact of unemployment on regional start-up activities: Audretsch and Fritsch (1994) find a negative influence of the unemployment rate using the labour market approach, but a positive influence using the ecological approach. Brixy and Grotz (2002, p. 117) discover a positive influence of the unemployment rate on the number of start-ups in all sectors, but a negative influence on the number of start-ups in manufacturing and business services. Fritsch and Falck (2002) find a low start-up propensity for unemployed persons. 


\subsection{Macroeconomic, institutional and policy framework}

The extent and nature of entrepreneurial activity in an economy is strongly influenced by the national institutional and policy framework. On the one hand, the general macroeconomic framework conditions of a country, including the taxation system, labour market regulations and the social security system, affect the risk/ reward profile of entrepreneurship. On the other hand, specific government programmes aimed at self-employment affect start-up activities (see Ilmakunnas and Kanniainen, 2001; Reynolds et al., 2004; Verheul et al., 2002b).

Germany is a country with a high level of prosperity and stability and a well-developed social security system. In the past, the high level of unemployment benefits seems to have been one reason for the relatively low start-up propensity among unemployed persons. At the same time - as explained above - a number of support programmes for entrepreneurship have been developed in recent decades. Germany can thus be characterised as a country where government intervention has played a crucial role in the development of entrepreneurship. The social security system and labour market regulations provided a high level of security for employed and unemployed people, thereby reducing the incentive to start a new business. On the other hand, there is a broad range of government programmes that support the move into self-employment (Verheul et al., 2002a, p. 53f).

There is only limited empirical evidence concerning the impact of specific government programmes or policies on entrepreneurship. Studies comparing different countries have to deal with the problem of different institutional backgrounds in different countries. Longitudinal studies are confronted with a number of influences on start-up activities that are also subject to constant change. Furthermore, most government programmes focus on a relatively small number of typically larger start-ups and do not reach the majority of small and part-time entrepreneurial activities. A number of those start-ups supported would also have been started without government support.
It is therefore very difficult to measure the direct influence of government programmes on the nature and extent of start-up activities (Verheul et al., 2002b, p. 53f).

The recent policy changes in Germany have made the option of starting a new business more attractive for unemployed people while at the same time being more restrictive in terms of unemployment benefits. As explained earlier, being made redundant is a triggering event that can lead people to start a business when they consider it a feasible alternative to unemployment. We therefore hypothesise that the recent policy changes have increased the start-up propensity among unemployed people. Although these policies are not region-specific (while other policies indeed are), they nevertheless have a regional impact (i.e., an effect that differs between regions) because they have greatest effect in regions with high or rising unemployment. In contrast to other programmes, the high number of recipients of bridging allowances can be expected to have a measurable effect on the magnitude and regional structure of entrepreneurial activities.

\section{Data}

In this paper, we use data from the adult population surveys of the Global Entrepreneurship Monitor in Germany. The Global Entrepreneurship Monitor is an annual assessment of national levels of entrepreneurial activity. GEM was initiated in 1999 with 10 countries, and almost continuously expanded to 35 countries in 2005 . The research programme, based on a harmonised assessment of the level of national entrepreneurial activity in all participating countries, involves the exploration of national features associated with the level of entrepreneurship and the role of entrepreneurship in national economic growth. A detailed description of the GEM methodology and data can be found in Reynolds et al. (2005). The most critical of all the data collection activities within the GEM program is the development of a method for estimating the level of national entrepreneurial activity. The GEM adult population surveys provide direct estimates of the level of participation by the adult population in 
new firm creation. The GEM adult population surveys are completed in each participating country to provide harmonised estimates of the level of entrepreneurial activity and are designed to generate representative samples of the adult population. The rate of nascent entrepreneurs reflects the prevalence of individuals who are currently in the process of starting a new business in the adult population. A GEM Global Report (see Minniti et al., 2006 for the 2005 edition) and a GEM country report Germany (see Sternberg et al., 2006 for the 2005 edition) is available for each year since 1999 .

The number of people interviewed in the GEM adult population survey in Germany has been considerably higher than the minimum sample size of 2000 respondents every year since the year 2000. So, at least for Germany, GEM data, originally intended for international comparisons (entire countries), also allows interregional analyses, as demonstrated by previous publications (Rocha and Sternberg, 2005; Sternberg, 2004; Sternberg and Bergmann, 2003).

Where possible, we use individual microlevel data and not aggregated data for whole regions in order to avoid "ecological fallacies" (Robinson, 1950). The availability of micro-level data is a major advantage of the GEM project since it makes it possible to combine individual characteristics of the founder and characteristics of the region where the person lives in a single analysis. The individual data from the telephone survey is combined with regional data from official statistics. We distinguish between 97 German planning regions ("Raumordnungsregionen"). In most cases, these regions are bigger than single cities and smaller than federal states. They usually consist of a city and its surroundings.

This paper focuses on nascent entrepreneurship, which also acts as dependent variable in the econometric analyses. The concept of nascent entrepreneurship is specific to GEM and gives a very up-to-date picture of entrepreneurial activities. It has been the focus of several GEM publications. Everybody who is currently in the process of setting up a business that he or she will (partly) own and that has not yet paid wages or salaries for more than three months counts as a nascent entrepreneur (see Reynolds et al., 2005).
We furthermore distinguish between two main motives for starting a business: Nascent opportunity entrepreneurship focuses on current start-up attempts which are based on a business opportunity, whereas nascent necessity entrepreneurship focuses on start-up attempts where the lack of alternative employment is the main reason for starting the business. In contrast to the usual GEM-approach in this paper only those founders count as opportunity entrepreneurs, who explicitly state "to take advantage of a business opportunity" as the reason for starting a business. All the other founders, including mixtures of different start-up reasons, count as necessity entrepreneurs. These founders account for approximately $20 \%$ of all nascent entrepreneurs. We chose to proceed in this way because we assume that it is highly socially desirable for a firm to be launched to pursue a good business idea. Nobody likes to admit having chosen self-employment only for the lack of a better job alternative. A significant number of those interviewed will therefore choose a combination of both motives, even if the main reason was the lack of alternative employment. Nascent entrepreneurship is the sum of the opportunity and the necessity components. These three different start-up activities (nascent entrepreneur, nascent opportunity entrepreneur, nascent necessity entrepreneur) act as dependent variables in our different models. In this paper we use the data from the years 2001 to 2004 since the distinction between opportunity and necessity entrepreneurship is only possible for these years.

There have been considerable changes in the extent and nature of entrepreneurial activities in the years 2001-2004 in Germany. The rate of the nascent entrepreneurs has continuously declined (see Figure 1). The decrease from 2001 to 2002 is conspicuously high, whereas the decrease is subsequently more moderate. Clearly the end of the new economy boom (in Germany in 2002) not only led to a drastic reduction in the number of dot.com start-ups in the Internet economy, but it also had a negative impact on the overall number of start-ups. Furthermore and more importantly for the further argumentation of this paper - the respective rates of the two entrepreneurial motives surveyed in 


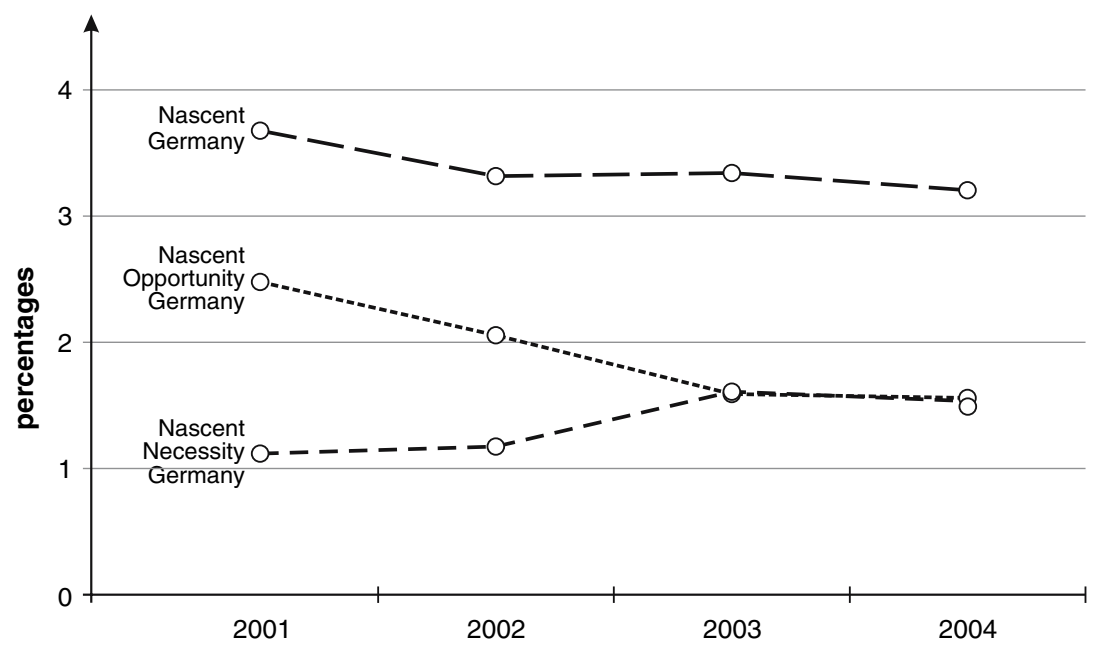

Figure 1. Rate of nascent entrepreneurs in Germany in the years 2001-2004. Data source. Global Entrepreneurship Monitor (GEM), adult population survey Germany 2001-2004.

GEM have shifted: Opportunity entrepreneurship has decreased considerably, necessity entrepreneurship has increased. In 2003 and 2004 the two measures had almost the same values.

Figure 2 shows the change in the regional rate of nascent entrepreneurs from 2001/2002 to $2003 / 2004$. It can be seen that in most of the planning regions in Eastern Germany entrepreneurship has increased or remained stable. There are only three out of 21 planning regions in Eastern Germany where the rate of nascent entrepreneurs has declined. It can be assumed that the increase in entrepreneurship in the majority of the East-German regions can mainly be attributed to necessity entrepreneurship due to the high unemployment in these regions. This proposition will be investigated in the following parts of this paper. On the other hand regions with a low level of unemployment, especially in the south of Germany, generally show a decrease in the rate of nascent entrepreneurship.

While three different start-up activities act as dependent variables in our models, we use the following independent variables in our models:

Person-related variables

\section{- Gender}

- Age (in years)

- Age (squared). The squared value of age (in years) is included as a separate variable in the models in order to be able to identify non- linear relationships between age and start-up activity.

- Gainfully employed (yes/no). We distinguish between people who are currently working or are unemployed in contrast to people who are still in training, housewives/househusbands or already retired. Unfortunately, the data does not allow the differentiation between people who are working and people who are unemployed.

- Higher education (yes/no). We distinguish between people who have "Abitur" (university entrance level qualification) and/or who have a university degree and people who do not have such qualifications.

- Self-employed (yes/no). People who are currently trying to start a new business can at the same time already be self-employed in any form. We distinguish between these people and people who are not self-employed.

Regional variables

- Change of regional rate of unemployment. Change in percentage points from 1999 to 2001 (for 2001 models) or from 2001 to 2003 (for 2003/2004 models).

- Agglomeration (yes/no). Regions with a population density of 300 inhabitants $/ \mathrm{km}^{2}$ or more are counted as agglomerations (based on the classification of the German "Bundesamt fuer Bauwesen und Raumordnung"). 


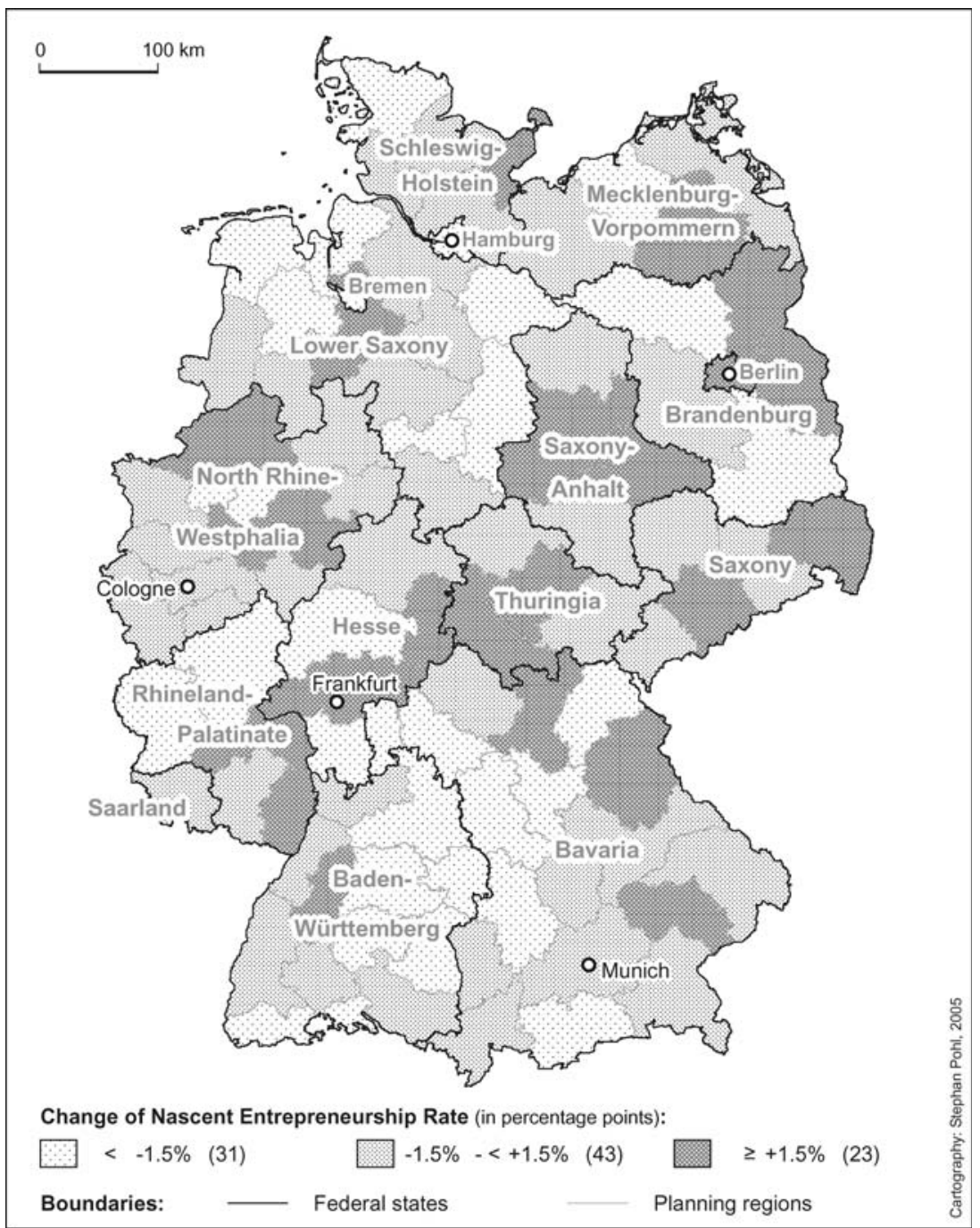

Figure 2. Change in regional rate of nascent entrepreneurship from 2001/2002 to 2003/2004. Data source. Global Entrepreneurship Monitor (GEM), adult population survey Germany 2001 and 2002.

- GDP/capita. GDP per inhabitant in euros in the year 2000 (for the 2001 models) or the year 2002 (for the 2003/2004 models). These are the most recent GDP data available for German regions. ${ }^{1}$.

- Change of GDP per capita. Change (in \%) of GDP per inhabitant from 1998 to 2000 (for the 2001 models) or from 2000 to 2002 (for the 2003/2004 models).

- Rate of self-employment. Percentage of selfemployed to all gainfully employed persons in the region. Data for 2001 (for 2001 models) or for 2003 (for 2003/2004 models).

In addition to these regional variables we also included the distinction between Eastern and Western Germany and the regional rate of unemployment in prior versions of the models. However, these variables did not prove to be significant in any of the models or correlate strongly with other variables. These variables were therefore abandoned in the final models. 


\section{Method}

The aim of this paper is to investigate factors that influence the decision to start a new business. As described above, the start-up decision is influenced by individual as well as regional factors, which leads to the question of how to combine the data of the different levels. Most of the studies on regional differences in start-up activities use aggregated data for regional entities. However, in this paper we evaluate the start-up decision at the individual level for the following reasons: Aggregating individual variables to the regional level leads to a shift in meaning: An aggregated variable refers to the macro-units and not directly to the micro-units (see Snijders and Bosker, 1999, p. 13). Reynolds (2005, p. 360) puts it this way: "Regional characteristics do not start businesses, people start new businesses". Furthermore, using aggregated data can lead to "ecological fallacies" (Robinson, 1950), because correlations between macro-level variables do not necessarily have to exist on the micro-level.

The data of the adult population survey of the Global Entrepreneurship Monitor has the advantage of being available at the micro-level. We therefore investigate the start-up decision at the individual level; the regional variables are disaggregated, i.e. every observation in the region is given the same values for the regional variables.

The dependent variable has only two possible values: A person can either be active in starting a business (coded as 1) or not (coded as 0 ). We test the influence of the independent variables described above on three different types of startup activities: nascent entrepreneurship, nascent opportunity entrepreneurship, nascent necessity entrepreneurship. A logit model is used which is suitable for binary dependent variables.

The disaggregation of regional data can in some ways be problematic as well. As described by Moulton (1990), the combination of data from individual observations with regional data can lead to misinterpretations when analysing them together in the same multivariate models. Aggregate variables used as explanatory variables in regressions based on microeconomic data can result in an underestimation of the standard error since the observations within one cluster are typically correlated. One way to avoid this problem is to use a special survey estimator that takes account of the clustering of the data. We therefore work with the "svylogit" survey estimator in STATA and take the region as primary sampling unit. ${ }^{2}$

Of particular importance with regard to the methodical approach applied for this paper is the fact that there was a major change in German labour market policy between 2002 and 2003. The "Me Inc." ("Ich- $A G$ ") instrument was introduced on 1 January 2003 and led to a considerable increase in the number of start-ups being launched by the unemployed. In parallel with this development, the number of recipients of bridging allowances, which had been in existence for longer, rose considerably. Overall, the number of necessity entrepreneurs has therefore increased by a large amount since the beginning of 2003 for the aforementioned reasons. This justifies differentiation in economic analyses between investigation periods before and since 2003.

The first decision that had to be made was whether to combine the survey data of subsequent years or whether to use data of single years only. The advantage of combining the surveys of subsequent years is that it enhances the possibility of analysing regional influences. However, there might be changes in framework conditions or the general state of the economy that make it impossible to combine data from two different years. Obviously the policy changes from 2002 to 2003 concerning start-ups from unemployment mean the data from before and after the change cannot be combined for use in a single model. Our original idea was to carry out a comparative investigation of entrepreneurial behaviour in 2001/2002 against the years $2003 / 2004$. To establish whether it was justified to combine the aforementioned years for investigation, logit models were developed (comparable with those upon which the results in Tables I and II are based), each of them also including a dummy variable to differentiate between the years. This dummy variable was not significant for the calculations with the combined data set from the years 2003 and 2004. Figure 1 also makes clear that the entrepreneurial behaviour scarcely changed 
TABLE I

Determinants of belonging to different start-up groups 2001 (results of logit-regressions)

\begin{tabular}{|c|c|c|c|c|c|c|c|c|c|}
\hline & \multicolumn{3}{|l|}{ Nascent } & \multicolumn{3}{|c|}{ Nascent opportunity } & \multicolumn{3}{|c|}{ Nascent necessity } \\
\hline & Coef. & $\mathrm{t}$ & Sig. & Coef. & $\mathrm{t}$ & Sig. & Coef. & $\mathrm{t}$ & Sig. \\
\hline \multicolumn{10}{|l|}{ Person-related variables } \\
\hline Gender $(1=$ male $)$ & 0.93044 & 4.640 & $* *$ & 0.98679 & 4.240 & $* *$ & 0.67015 & 2.020 & $* *$ \\
\hline Age (in years) & 0.08053 & 1.600 & & 0.07467 & 1.240 & & 0.16971 & 1.490 & \\
\hline Age squared & -0.00133 & -2.170 & $* *$ & -0.00144 & -1.810 & $*$ & -0.00200 & -1.480 & \\
\hline Combined significance of two age variables ${ }^{\mathrm{a}}$ & & & $* *$ & & & $* *$ & & & \\
\hline Gainfully employed $(1=$ yes $)$ & 0.43903 & 1.730 & $*$ & 0.61275 & 2.170 & $* *$ & 0.01586 & 0.030 & \\
\hline Higher education $(1=$ yes $)$ & 0.42965 & 2.660 & $* *$ & 0.52068 & 3.010 & $* *$ & 0.20296 & 0.680 & \\
\hline Self-employed $(1=$ yes $)$ & 1.66303 & 7.570 & $* *$ & 1.61509 & 6.610 & $* *$ & 1.64594 & 4.410 & $* *$ \\
\hline \multicolumn{10}{|l|}{ Regional variables } \\
\hline Change of unemployment rate (in \%) 1999-2001 & -0.33507 & -2.480 & $* *$ & -0.46132 & -3.450 & $* *$ & -0.05185 & -0.240 & \\
\hline Agglomeration $(1=$ yes $)$ & 0.07443 & 0.370 & & 0.14642 & 0.630 & & -0.14874 & -0.470 & \\
\hline GDP/capita 2000 (in EURO) & -0.00005 & -2.310 & $* *$ & -0.00009 & -3.900 & $* *$ & 0.00003 & 0.940 & \\
\hline Change of GDP/capita 1998-2000 (in \%) & -0.00928 & -0.220 & & -0.01480 & -0.300 & & -0.01252 & -0.250 & \\
\hline Self-employment rate 2001 (in \%) & 0.12939 & 2.190 & $* *$ & 0.18887 & 2.940 & $* *$ & -0.01931 & -0.210 & \\
\hline Constant & -5.98970 & -5.740 & $* *$ & -6.06186 & -5.460 & $* *$ & -9.03662 & -3.930 & $* *$ \\
\hline$N$ & 5249 & & & 5266 & & & 5266 & & \\
\hline$F(11,86)$ & 19.66 & & & 13.64 & & & 5.83 & & \\
\hline Prob $>F$ & 0.000 & & & 0.000 & & & 0.000 & & \\
\hline
\end{tabular}

Data source. Global Entrepreneurship Monitor (GEM), adult population survey Germany 2001.

*Significant on $10 \%$-level.

**Significant on $5 \%$-level.

${ }^{\text {a }}$ The variable age was introduced into the models in single form and as age-squared in order to control for non-linear relationships. In all the described models the age variable has a positive impact on the probability of starting a new business whereas the age-squared variable has a negative influence. Therefore the combined influence of age on self-employment takes a inverse u-shaped form. The combined significance of the two age variables is tested by using an adjusted Wald-test.

from 2003 to 2004. The years 2003 and 2004 are therefore investigated together in all of the following calculations.

The years 2001 and 2002 produced a different picture. Figure 1 already shows that there were considerable differences between the two years. When the two years were combined to create a single data set, the dummy variable included to differentiate between the two years in the calculation of factors influencing entrepreneurial activities proved to be significant in the case of nascent opportunity entrepreneurship. This is a clear indication that it is not possible to view the two years 2001 and 2002 together. The year 2001 is therefore investigated separately in the following. The results for that year are then compared with the results for 2003/2004.

The calculations for 2001 are based on the interviews of 5308 persons aged 18-64. The $2003 / 2004$ data set consists of 11,405 persons in this age group. Due to missing values the reported number of observations is slightly lower in the models.

\section{Results: what factors determine start-up activities in German regions?}

\subsection{Results for start-up activities in 2001}

The following Table I summarises the results for the 2001 models. $^{3}$ At the level of personrelated influential factors, the expected relationships were found: Women have a significantly lower entrepreneurial propensity than men in all four of the entrepreneurial activities investigated. When considering the age variables used here, the significance of one of the two variables should not be interpreted alone. The existence of a significant relationship between age and entrepreneurial propensity can only be investigated by means of a joint test of both age variables. The adjusted Wald test 
TABLE II

Determinants of belonging to different start-up groups 2003/2004 (results of logit-regressions)

\begin{tabular}{|c|c|c|c|c|c|c|c|c|c|}
\hline & \multicolumn{3}{|l|}{ Nascent } & \multicolumn{3}{|c|}{ Nascent opportunity } & \multicolumn{3}{|c|}{ Nascent necessity } \\
\hline & Coef. & $\mathrm{t}$ & Sig. & Coef. & $\mathrm{t}$ & Sig. & Coef. & $\mathrm{t}$ & Sig. \\
\hline \multicolumn{10}{|l|}{ Person-related variables } \\
\hline Gender $(1=$ male $)$ & 0.55569 & 3.940 & $* *$ & 0.74789 & 4.590 & $* *$ & 0.30291 & 1.560 & \\
\hline Age (in years) & 0.04176 & 1.030 & & 0.02831 & 0.540 & & 0.06042 & 0.980 & \\
\hline Age squared & -0.00088 & -1.780 & $*$ & -0.00095 & -1.470 & & -0.00086 & -1.140 & \\
\hline Combined significance of two age variables ${ }^{a}$ & & & $* *$ & & & $* *$ & & & \\
\hline Gainfully employed $(1=$ yes $)$ & 0.25625 & 1.240 & & 0.19770 & 0.560 & & 0.26664 & 1.050 & \\
\hline Higher education $(1=$ yes $)$ & 0.27270 & 1.960 & $*$ & 0.46049 & 1.930 & $*$ & 0.05799 & 0.350 & \\
\hline Self-employed $(1=$ yes $)$ & 1.78639 & 11.960 & $* *$ & 1.97020 & 10.220 & $* *$ & 1.49631 & 6.910 & $* *$ \\
\hline \multicolumn{10}{|l|}{ Regional variables } \\
\hline Change of unemployment rate (in \%) 2001-2003 & 0.21244 & 2.220 & $* *$ & 0.16536 & 1.230 & & 0.26212 & 1.910 & $*$ \\
\hline Agglomeration $(1=$ yes $)$ & 0.35341 & 2.600 & $* *$ & 0.40860 & 2.190 & $* *$ & 0.31761 & 1.460 & \\
\hline GDP/capita 2002 (in EURO) & -0.00002 & -1.680 & $*$ & 0.00000 & -0.270 & & -0.00004 & -1.970 & $*$ \\
\hline Change of GDP/capita 2000-2002 (in \%) & 0.02865 & 1.300 & & 0.02252 & 0.700 & & 0.04558 & 1.320 & \\
\hline Self-employment rate 2003 (in \%) & 0.00320 & 0.070 & & -0.00538 & -0.100 & & 0.01317 & 0.200 & \\
\hline Constant & -4.58316 & -5.080 & $* *$ & -5.19770 & -4.800 & $* *$ & -5.60538 & -3.940 & $* *$ \\
\hline$N$ & 11187 & & & 11212 & & & 11212 & & \\
\hline$F(11,86)$ & 25.53 & & & 27.32 & & & 10.08 & & \\
\hline Prob $>F$ & 0.000 & & & 0.000 & & & 0.000 & & \\
\hline
\end{tabular}

Data source. Global Entrepreneurship Monitor (GEM), adult population survey Germany 2003 and 2004.

*Significant on $10 \%$-level.

** Significant on $5 \%$-level.

${ }^{\text {a }}$ The variable age was introduced into the models in single form and as age-squared in order to control for non-linear relationships. In all the described models the age variable has a positive impact on the probability of starting a new business whereas the age-squared variable has a negative influence. Therefore the combined influence of age on self-employment takes a inverse u-shaped form. The combined significance of the two age variables is tested by using an adjusted Wald-test.

demonstrates a significant relationship in the case of nascent and nascent opportunity entrepreneurship. Age has no significant influence on entrepreneurial propensity in the case of nascent necessity start-ups. Necessity startups are therefore launched largely independently of the entrepreneurs' age, which makes sense, since a situation in which one is forced to become self-employed due to the lack of alternative employment can arise regardless of one's age and therefore cannot be planned for. Age does, however, have a significant influence on the entrepreneurial propensity in the three other areas of entrepreneurial activity. The age variable (measured in years) is positive and the age (squared) variable negative, which implies a reversed U-shaped relationship. As already postulated in the theoretical section, the entrepreneurial propensity does indeed rise initially and then drops off over the remainder of the working life.
Higher education qualification has a positive influence on entrepreneurial propensity. As expected, those in gainful employment and the self-employed have a higher level of entrepreneurial propensity. Here too, however, there are differences between nascent opportunity start-ups and nascent necessity startups. In the case of necessity start-ups, the level of education does not influence whether a start-up is attempted, nor does it make any difference whether the entrepreneur was in gainful employment or not. Necessity start-ups are thus launched by people from widely varying educational and employment backgrounds.

Among the regional influential factors investigated, the change in the rate of unemployment proved to be significant for the various entrepreneurial activities: In regions where unemployment rose, there was a lower number of start-ups in 2001. Once again, this relationship 
does not apply to necessity start-ups, however, where no significant influence was found.

There is a negative correlation between the GDP per capita and nascent opportunity startups and nascent start-ups as a whole, which is surprising. This result probably means that regions with high levels of GDP per capita offered a range of other employment opportunities, which made launching a start-up appear relatively unattractive. Although the question of whether someone is self-employed or not is already taken into account at individual level among the person-related influential factors, the regional rate of self-employment proved to be significant for three of the four areas of entrepreneurial activity investigated. Accordingly, regions with a high proportion of self-employed have a different entrepreneurship culture or climate than regions with a low percentage of self-employed people. The positive relationship between self-employment and start-up propensity may also be due to role-model effects.

It should be emphasised that there are considerable differences between the factors influencing nascent opportunity start-ups and nascent necessity start-ups. The results for opportunity start-ups and nascent entrepreneurship in general largely correspond with theoretical predictions. The factors influencing necessity start-ups, on the other hand, are far more difficult to determine. Overall, only two significant influential factors could be found for this type of start-up.

\subsection{Results for start-up activities in $2003 / 2004$}

Table II summarises the results for the 2003/ 2004 models. Comparison of the results for years 2003/2004 and those for the year 2001 shows that there are similarities between the two periods. But there are also some remarkable differences. First the similarities: Similar to the year 2001, the results for $2003 / 2004$ also show the expected relationships between gender, age, level of education, self-employment and nascent (opportunity) entrepreneurship. Women have a lower entrepreneurial propensity than men. The joint investigation of the significance of the two age variables (on the basis of an adjusted Wald test) identifies a significant relationship for nascent and nascent opportunity. The relationship between age and entrepreneurial propensity once again generates a reversed U-shape. In the case of nascent necessity entrepreneurship, however, there is no significant influence of age on the entrepreneurial propensity.

In contrast to the year 2001, however, the employment situation has no influence on the entrepreneurial propensity in $2003 / 2004$, which indicates that students, housewives/househusbands and pensioners do not have a lower startup propensity than employed people as in the case of 2001.

Necessity entrepreneurship is a phenomenon which is also very difficult to explain for the years $2003 / 2004$ based on person-related factors. In contrast to 2001, gender also proves no longer to be a significant factor in 2003/2004. The difference in the start-up rate between men and women can therefore be attributed to influential factors other than gender.

There is a range of differences between the years 2001 and 2003/2004 in terms of the regional influential factors. The most striking difference is that a change in the regional rate of unemployment does not lead to a lower, but to a higher probability of starting a business. This point will be discussed below. In contrast to 2001 people in agglomerations are more likely to start a new business. There is also a slight positive correlation between GDP per capita and the propensity to start a new business.

So far, the discussion of results has concentrated solely on the statistical significance of single variables. However, a variable might be statistically significant but still only have a marginal effect on start-up-activities. Unfortunately the results of logit models are difficult to interpret. The coefficients do not show the influence of a one unit change of the independent variable on the dependent variable as in a linear regression model but on the logged odds. However there is a way to ease the interpretation of the results by calculating the estimated values of the dependent variable, i.e. the probability of starting a business for certain groups in the model. The next step makes it possible to analyse how a change of one independent variable affects the estimated 
probability of the dependent variable (see Long and Freese, 2003; Wagner, 2003). ${ }^{4}$ In our view, the most significant change between 2001 and $2003 / 2004$ is the reversal of the direction of influence of a change in the regional rate of unemployment on nascent entrepreneurship activities. We therefore calculated the probability of becoming a nascent entrepreneur depending on the percentage change of the regional rate of unemployment; all other independent variables are fixed at their sample means. We distinguish between nascent entrepreneurship in general, nascent opportunity entrepreneurship and nascent necessity entrepreneurship. Figure 3 shows the results for 2001 and it can be seen that the probability of becoming a nascent entrepreneur decreases with an increase in the regional rate of unemployment. However, this decrease can mainly be attributed to opportunity entrepreneurship, while the necessity component stays almost constant. The results for 2003/2004 (Figure 4) show a different picture: the curve for nascent entrepreneurship shows a marked rise as it progresses. In regions with increasing unemployment, the probability of launching a startup is considerably higher than in the regions with a stable level of unemployment. This rise is due to necessity entrepreneurship and - to a lesser extent - to opportunity entrepreneurship.
Both types of nascent entrepreneurship increase as the regional rate of unemployment rises.

\section{Discussion}

The changed relationship between the rate of unemployment and entrepreneurial activities may have many causes. The development of the economy as a whole and the increasing level of unemployment in Germany no doubt contributed to the increase in the number of necessity start-ups. But this does not fully explain why the relationship between the rate of unemployment and entrepreneurial activity also reversed at regional level. While in the year 2001, regions where the rate of unemployment had increased over the previous years were confronted with a decrease in the entrepreneurial propensity of the individual, this relationship has now reversed. As the regional rate of unemployment increases, so currently does the entrepreneurial propensity of the individual. We argue here that not only the overall development of the economy, but also the change and considerable expansion of the range of support instruments available for launching start-ups from unemployment in particular is responsible for the reversal described above. The media-friendly treatment of the subject of self-employment and buzzwords such as "Ich- $A G$ " ("Me Inc.") have

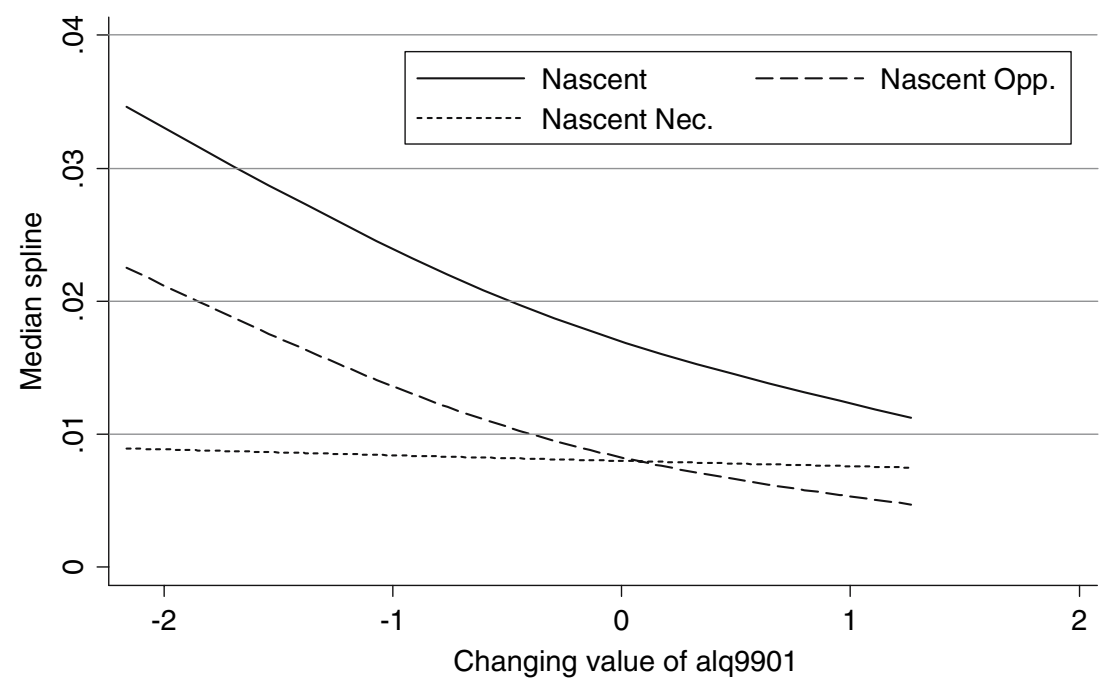

Figure 3. Estimated probability of becoming a nascent entrepreneur (in 2001) depending on the change of the regional rate of unemployment from 1999 to 2001. Data source. Global Entrepreneurship Monitor (GEM), adult population survey Germany 2001, regional labour statistics (various years). 


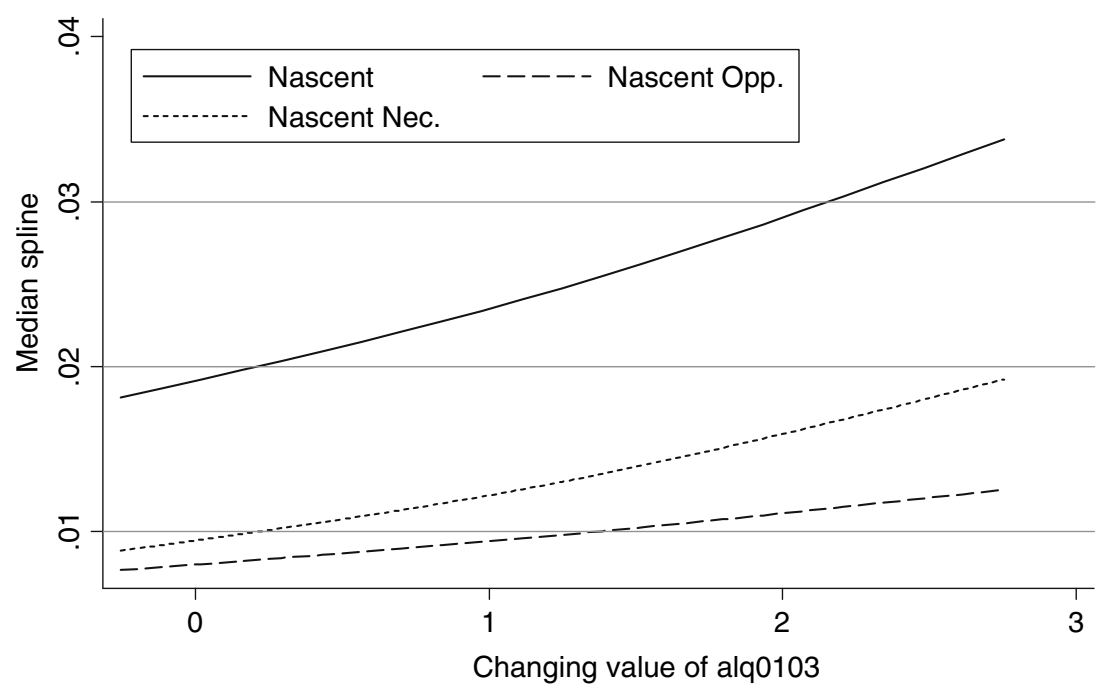

Figure 4. Estimated probability of becoming a nascent entrepreneur (in 2003/2004) depending on the change of the regional rate of unemployment from 2001 to 2003. Data source. Global Entrepreneurship Monitor (GEM), adult population survey Germany 2001 and 2003, regional labour statistics (various years).

considerably increased the acceptance and chances of launching a start-up from unemployment. It can be assumed that in 2003 and 2004 almost every unemployed person in Germany knew that he or she could get financial support when starting a business. It is difficult to estimate what effect the policy changes would have had without the intensive media coverage of the topic.

Shapero's approach (1984) described earlier in this paper also helps to explain why people who have just become unemployed have a higher entrepreneurial propensity than those who have not just suffered such a displacement. The precondition for this, however, is that the person thinks a start-up can succeed and is worth working for. Under these conditions, an increase in the rate of unemployment in a region can go hand in hand with a higher regional rate of start-ups. Start-ups from unemployment were rather unusual in the past and most studies for the 1980s and 1990s show a negative relationship between the rate of unemployment and entrepreneurial activities. The increase in the number of measures to support start-ups from unemployment, in particular since 2003, however, have promoted the view that start-ups from unemployment really can succeed and are worth working for. Regions with an increase in unemployment therefore have a higher start-up rate than regions where the level of unemployment is stable. As a result of the massive promotion of start-ups from unemployment, a displacement is increasingly frequently seen as the trigger for the move to self-employment.

One could have assumed that the new support instruments for start-ups from unemployment have a stronger effect in Eastern Germany than in Western Germany. In Eastern Germany - as a former socialist country - people tend to demand and rely on state support somewhat more than in Western Germany. However, the variable for Eastern Germany did not prove to be significant in any of the models and was therefore abandoned in the final models. Socioeconomic characteristics of the regions seem to explain regional differences in start-up propensities. There is no specific influence of East vs. West Germany. While the socialist past (with its implication for entrepreneurial attitudes) is still rather present in the minds of several of the elder people in East Germany this is not true for the majority of members of the younger generation born in the 1980s and 1990s.

Comparing the results for 2001 and 2003/ 2004 there are also changes in the significance of the regional variables "agglomeration", "GDP/ capita" and "rate of self-employment". In our 
view, these changes are mainly due to the deteriorated macroeconomic situation in Germany as a whole. The year 2001 was characterised by an economic slow-down. However, in 2003 and 2004 the economic situation was still worse with higher unemployment and low growth rates. In an economic crisis the propensity to start a new business might be higher in agglomerations and regions with a high GDP/capita because of two reasons. First, most necessity start-ups and start-ups from unemployment are established in the service sector which often require a certain size of the regional market in terms of number of customers and purchasing power. Second, people might generally see better chances for profitability in agglomerations and regions with a high GDP/capita. As stated above, a personal displacement will only lead to a business startup if the person believes a start-up to be promising alternative that is worth working for. Bergmann (2004, p. 179) and Sternberg and Bergmann (2003, p. 38) show that people in Germany tend to see better opportunities for starting a business in agglomerations and regions with a high purchasing power/capita. The entrepreneurship culture or climate of a region (measured in terms of the rate of self-employment), which was a significant determinant in 2001, becomes less important in an economic depression because people need to focus on profitability rather on their preferred employment alternative.

\section{Conclusion}

This paper has shown that both individual and regional variables have an influence on the decision to become self-employed. All models investigated showed a considerable difference between opportunity and necessity start-ups. These differences reconfirm the chosen allocation of opportunity versus necessity, whereby only those entrepreneurs are classed as opportunity entrepreneurs who explicitly state "to take advantage of a business opportunity" as the reason for starting a business.

For the most part, the results for opportunity nascents and nascent start-ups in general are in line with the theoretical predictions. The factors influencing necessity start-ups, on the other hand, are far more difficult to determine. These start-ups for lack of alternative employment opportunities are predominantly launched independently of the entrepreneurs' age, gender, level of education and regional influences, due to the individual's perception of a situation of economic need.

The results of our analysis confirm the assumption that recent policy changes have changed the individual start-up propensity in Germany. Unfortunately the data does not allow to distinguish between people who have been unemployed before starting a business and those who have not. However, the results suggest that people who have become unemployed have a higher start-up propensity after the policy changes in 2003 than before. As a result of the massive promotion of start-ups from unemployment, a displacement is increasingly frequently seen as the trigger for the move to self-employment. There should be further research based on longitudinal micro-level data to confirm this proposition.

Our results furthermore show that policies without any regional focus can have substantial regional implications. The individual start-up propensity in regions with rising unemployment is different from that in regions with stable or decreasing unemployment. Recent policy changes aimed at start-ups from unemployment have the greatest impact in regions with rising unemployment.

Further research will have to be carried out to determine whether the observed change in the regional structure of entrepreneurship behaviour and its regional determinants is permanent or whether it is merely a result of the current macroeconomic situation and current entrepreneurship policies. It will also soon be clear whether the run on the "Ich- $A G$ " (Me Inc.) and bridging allowances will continue. Initial academic evaluations of both instruments (e.g. concerning the survival rate of these start-ups) will soon be available and may, under certain circumstances, force a change in thinking. In addition, there is much to suggest that the number of "Ich- $A G$ " firms will not continue to rise at its current rate. Since autumn 2004, people applying to register an "Ich- $A G$ " have to 
submit at least a very rough business plan which was previously not the case. This could lead to an increase in the quality of these startups; equally, however, the number of those given support and therefore the number of (necessity) entrepreneurs could also fall.

Despite the uncertainty about the sustainability of the new wave of start-ups from unemployment this recent development may still have long-term implications. A number of people who have started a business recently might not have done so without government assistance. As a result people with different backgrounds and from different industries now have experience in starting a business. In the past the relatively low level of self-employment experience in Eastern Germany and in regions with a large-scale industrial structure has restrained people from starting a business. The recent upturn in the number of start-ups - although often out of necessity reasons - may increase entrepreneurial experience and awareness and have positive effects on entrepreneurship in Germany in the long run.

\section{Notes}

1 There is only a weak relationship between the status of being an agglomeration and the GDP per capita so that both variables could be included into the models. On average agglomerations tend to have a higher GDP per capita than other regions. However, there are also old industrial regions and regions in East-Germany which are agglomerations but still only have a low GDP per capita. E.g. in Berlin, the biggest city in Germany, GDP per capita is slightly below the German average.

2 The svylogit command is especially designed for complex survey data. The svylogit command takes into account that observations within one cluster (i.e. region) are not independent. Accounting for clustering is necessary to obtain "honest" estimates of standard errors. The point estimates from the svylogit command are exactly the same as the point estimates from a standard logit regression. Goodness-of-fit measures do not apply to the svylogit command, they are therefore not reported in the following results (see Stata Corporation, 2003, p. 343).

3 We also calculated models which include only personrelated variables and no regional variables. These models delivered very similar results for the person-related variables as the models including the regional variables. There are only slight changes in the significance level of some of the variables. Since there are no standard measures for goodness-of-fit for the used survey estimators, which could be used to compare the results of different models, the models without the regional variables are not reported in this paper.

4 These calculations were made using the programme "SPOST for Stata". For further information, please refer to: www.indiana.edu/ jslsoc/spost.htm.

\section{References}

Armington, C. and Z. J. Acs, 2002, 'The Determinants of Regional Variation in New Firm Formation', Regional Studies 36, 33-45.

Audretsch, D. B. and M. Fritsch, 1994, 'The Geography of Firm Births in Germany', Regional Studies 28, 359-365.

Bartik, T. J., 1989, 'Small Business Start-Ups in the United States: Estimates of the Effects of Characteristics of States', Southern Economic Journal 55, 1004-1018.

Bates, T., 1995, 'Self-Employment Entry across Industry Groups', Journal of Business Venturing 10, 143-156.

Bergmann H., 2004, Gruendungsaktivitaeten im regionalen Kontext, Gruender, Gruendungseinstellungen und Rahmenbedingungen in zehn deutschen Regionen [Start-up Activities in a Regional Context, Founders, Entrepreneurial Attitudes and Framework Conditions in ten German Regions], Koelner Forschungen zur Wirtschafts- und Sozialgeographie, 57, Cologne: Institute of Economic and Social Geography.

Brixy, U. and R. Grotz, 2002, 'Raeumliche Differenzierungen von Betriebsgruendungen und Ueberlebenschancen in Westdeutschland 1983 bis 1997 [Spatial Differenciation of Start-ups and Survival Chances in West-Germany 1983 to 1997]', Raumforschung und Raumordnung 60, 100-122.

Bygrave W. D., 1997, The Portable MBA in Entrepreneurship, 2nd ed., New York: John Wiley \& Sons.

Carter N., 1997, 'Entrepreneurial Processes and Outcomes: The Influence of Gender', in: P. D. Reynolds and S. B. White (eds.), The Entrepreneurial Process, Westport: Quorum Books.

Centre for European Economic Research (ZEW) (ed.), 2004, 'Ich-Ags fuehren zu mehr Gruendungen in Deutschland' [Me Inc. Lead to More Start-ups in Germany], ZEWGruendungsreport 4, 1-2.

Davidsson, P. and B. Honig, 2003, 'The Role of Social and Human Capital among Nascent Entrepreneurs', Journal of Business Venturing 18, 301-331.

Feldman, M. P., 2001, 'The Entrepreneurial Event Revisited: Firm Formation in a Regional Context', Industrial and Corporate Change 10, 861-891.

Fritsch M. and O. Falck, 2002, New Firm Formation by Industry over Space and Time: A Multi-Level Analysis, Freiberg Working Papers, Technical University of Freiberg, Faculty of Economics and Business Administration.

Ilmakunnas, P. and V. Kanniainen, 2001, 'Entrepreneurship, Economic Risks, and Risk Insurance in the Welfare State: Results with OECD Data 1978-93', German Economic Review 2, 195-218.

Knight, F. H., 1921, Risk, Uncertainty and Profit, Boston, New York: Houghton Mifflin Company; Cambridge: The Riverside Press, College Station, TX: Stata Press. 
Long, J. S. and J. Freese, 2003, Regression Models for Categorical Dependent Variables Using Stata, College Station TX: STATA Press.

Minitti, M., W. D. Bygrave and E. Autio, 2006, Global Entrepreneurship Monitor 2005 Executive Report, Babson College: London Business School.

Moulton, B. R., 1990, 'An Illustration of a Pitfall in Estimating the Effects of Aggregate Variables on Micro Units', Review of Economics and Statistics 72, 334-338.

Reynolds, P. D., 2005, 'Understanding Business Creation: Serendipity and Scope in Two Decades of Business Creation Studies', Small Business Economics 24, 359-364.

Reynolds, P. D., D. Storey and P. Westhead, 1994, 'CrossNational Comparisons of the Variation in New Firm Formation Rates', Regional Studies 28, 443-456.

Reynolds, P. D., W. D. Bygrave and E. Autio, 2004, Global Entrepreneurship Monitor, 2003 Executive Report, With contributions from Pia Arenius, Paula Fitzsimons, Maria Minniti, Sinead Murray, Colm O'Goran and Frank Roche, Babson College, London Business School, Ewing Marion Kauffman Foundation.

Reynolds, P., N. Bosma, E. Autio, S. Hunt, N. Bono, I. Servais, P. Lopez-Garcia and N. Chin, 2005, 'Global Entrepreneurship Monitor: Data Collection and Implementation 1998-2003', Small Business Economics 24, 205-231.

Robinson, P. B. and E. A. Sexton, 1994, 'The Effect of Education and Experience on Self-Employment Success', Journal of Business Venturing 9, 141-156.

Robinson, W., 1950, 'Ecological Correlations and Behavior of Individuals', American Sociological Review 15, 351-357.

Rocha, H. and R. Sternberg, 2005, 'Entrepreneurship: The Role of Clusters, Theoretical Perspectives and Empirical Evidence from Germany', Small Business Economics 24(3), 267-292.

Schulz N., 1995, Unternehmensgruendungen und Markteintritt [Firm Foundations and Market Entry], Heidelberg: Physica.

Shapero, A., 1984, 'The Entrepreneurial Event', in: C. A. Kent (ed.), The Environment for Entrepreneurship, Lexington/ Toronto: Lexington Books, pp. 21-40.

Shapero, A. and L. Sokol, 1982, 'The Social Dimensions of Entrepreneurship', in: C. Kent et al. (eds.), The Encyclopedia of Entrepreneurship, Prentice-Hall: Englewood Cliffs, pp. $72-90$.

Snijders, T. A. B. and R. J. Bosker, 1999, Multilevel Analysis, Sage: London.

Stata Corporation, 2003, Stata User's Guide, Release 8, Stata Corporation: College Station.

Sternberg, R., 2000, 'Entrepreneurship in Deutschland, Das Gruendungsgeschehen im internationalen Vergleich, Laenderbericht Deutschland 1999 zum Global Entrepre- neurship Monitor' [Entrepreneurship in Germany, An International Comparison of Entrepreneurial Activities, GEM Country Report Germany 1999], Berlin: Edition Sigma.

Sternberg, R., 2004, 'Entrepreneurship Research - The Relevance of the Region and Tasks Facing Economic Geography', Geographische Zeitschrift 92, 18-38.

Sternberg, R. and H. Bergmann, 2003, Global Entrepreneurship Monitor, Laenderbericht Deutschland 2002 [Global Entrepreneurship Monitor: Country Report Germany 2002], Cologne: Institute of Economic and Social Geography, University of Cologne.

Sternberg, R., H. Bergmann and I. Lueckgen, 2004, Global Entrepreneurship Monitor (GEM), Laenderbericht Deutschland 2003 [Global Entrepreneurship Monitor: Country Report Germany 2003], Cologne: Institute of Economic and Social Geography, University of Cologne.

Sternberg, R., U. Brixy and J.-F. Schlapfner, 2006, Global Entrepreneurship Monitor (GEM), Laenderbericht Deutschland 2005, [Global Entrepreneurship Monitor: Country Report Germany 2005], Hannover: Institute of Economic and Cultural Geography, Leibnitz University of Hannover.

Storey, D. J., 1994, Understanding the Small Business Sector, London: International Thomson Business Press.

Verheul, I., G. Leonardo, S. Schueller and J. van Spronsen, 2002a, 'Determinants of Entrepreneurship in Germany', in: Audretsch et al., Entrepreneurship: Determinants and Policy in a European-US Comparison, Dordrecht: Kluwer, pp. 163208.

Verheul, I., S. Wennekers, D. Audretsch and R. Thurik, 2002b, 'An Eclectic Theory of Entrepreneurship: Policies, Institutions and Culture', in: Audretsch et al., Entrepreneurship: Determinants and Policy in a European-US Comparison, Dordrecht: Kluwer, pp. 11-82.

Wagner, J., 2003, 'Taking a Second Chance, Entrepreneurial Restarters in Germany', Applied Economics Quarterly 49, 255-272.

Welter, F. and B. Lageman, 2003, Gruenderinnen in Deutschland - Potenziale und institutionelles Umfeld [Female Entrepreneurs in Germany - Potentials and Institutional Environment], Untersuchungen des Rheinisch-Westfaelischen Instituts fuer Wirtschaftsforschung, Heft 41, Essen: RWI.

Welter, F. and Rosenbladt B. V., 1998, 'Der Schritt in die Selbstaendigkeit, Gruendungsneigung und Gruendungsfaehigkeit in Deutschland [The Step into SelfEmployment, Start-up Propensity and Start-up Ability in Germany], Internationales Gewerbearchiv 46, 234-248. 